\title{
HUBUNGAN KEMANDIRIAN BELAJAR DAN HASIL BELAJAR IPS SISWA KELAS V SDN SEKECAMATAN KEBUMEN TAHUN AJARAN 2020/2021
}

\author{
Catur Fitri Anggoro ${ }^{1}$, Muh. Chamdani², Suhartono ${ }^{3}$ \\ Universitas Sebelas Maret \\ catur,gesing@gmail.com
}

\section{Article History}

accepted 1/11/2021

\begin{abstract}
Independence is one of the factors determining student's success, so that it is crucial for anyone who wants to be successful in life. The study aimed to analyze the correlation and the contribution of independence in learning on social science learning outcomes to fifth grade students of public elementary schools in Kebumen Sub-district in academic year of 2020/2021. It was correlational quantitative method. Sampling method was cluster random sampling techniques. Data analysis used SPSS 21 Version. The results showed that the correlation between independence in learning and social science learning outcomes had a correlation coefficient of 0.412. It indicated moderate correlation. Independence in learning contributed $16.9 \%$ on social science learning outcomes and the remaining $83.1 \%$ is influenced by other factors such as intelligence, interest, attention, learning motivation, perseverance, attitude, study habits, talent, environment, physical condition, and health. It concludes that there is a positive correlation between independence in learning and social science learning outcomes to fifth grade students. It meant that the higher student's independence in learning, the higher student's social science learning outcomes and vice versa.
\end{abstract}

Keywords: learning independence, social science learning outcomes

\begin{abstract}
Abstrak
Kemandirian merupakan salah satu faktor yang menentukan keberhasilan siswa, sehingga sikap mandiri ini sangat penting dimiliki oleh siapa saja yang ingin sukses dalam hidupnya. Penelitian ini bertujuan untuk menganalisis hubungan dan sumbangan kemandirian belajar dengan hasil belajar IPS siswa kelas V SDN se-Kecamatan Kebumen Tahun Ajaran 2020/2021 dengan metode korelasi. Pengambilan sampel dilakukan dengan teknik cluster random sampling. Peneliti menggunakan bantuan aplikasi SPSS versi 21 dalam menganalisis data. Hasil penelitian menunjukan hubungan kemandirian belajar dan hasil belajar IPS memiliki koefisien korelasi sebesar 0,412 , dengan tingkat hubungan moderat/sedang. Besarnya sumbangan variabel kemandirian belajar pada hasil belajar IPS yaitu sebesar $16.9 \%$ dan $83.1 \%$ dipengaruhi oleh faktor lain seperti kecerdasan, minat, perhatian, motivasi belajar, ketekunan, sikap, kebiasaan belajar, bakat, lingkungan, kondisi fisik dan kesehatan. Berdasarkan pembahasan dan analisis data penelitian dapat disimpulkan bahwa hubungan kemandirian belajar dan hasil belajar IPS siswa kelas $V$ memiliki hubungan positif di mana semakin tinggi kemandirian belajar siswa, maka akan semakin tinggi pula hasil belajar IPS siswa.
\end{abstract}

Kata kunci: kemandirian belajar, hasil belajar IPS 


\section{PENDAHULUAN}

Salah satu faktor yang mempengaruhi maju atau tidaknya suatu negara adalah pendidikan. Pendidikan diselenggarakan dengan mengembangkan budaya membaca, menulis, dan berhitung bagi segenap warga masyarakat. Dewasa ini, pada abad 21 ini pendidikan masih menjadi faktor penting dalam menjadi tolok ukur maju tidaknya suatu negara. Negara yang maju merupakan negara yang memiliki sumber daya manusia yang berkualitas karena dibentuk dengan pendidikan yang baik. Sumber daya manusia yang berkualitas tentunya harus memiliki keterampilan berpikir kritis, memecahkan masalah, berkomunikasi, berkolaborasi, kreatifitas, dan berinovasi. Salah satu usaha untuk menciptakan suasana belajar yang aktif adalah dengan cara merancang proses kegiatan pembelajaran yang dapat menumbuhkan potensi dan keterampilan siswa menjadi pribadi yang berkualitas sesuai dengan tujuan pendidikan nasional. Berdasarkan hasil observasi dan wawancara dengan guru-guru kelas $V$ di SD Kecamatan Kebumen, ditemukan beberapa masalah yang memengaruhi belajar siswa yaitu siswa kurang mandiri dalam proses pembelajaran dan media pembelajaran yang kurang memadai. Selain itu, dari hasil observasi juga diketahui bahwa hasil belajar IPS siswa kelas V SDN 6 Panjer dan SDN 1 Adikarso kurang maksimal, hal tersebut dibuktikan dari hasil nilai rata-rata Penilaian Tengah Semester pada mata pelajaran IPS siswa kelas V di SDN 6 Panjer yaitu 68. Sedangkan dari hasil nilai rata-rata Penilaian Tengah Semester pada mata pelajaran IPS siswa kelas V di SDN 1 Adikarso yaitu 69, nilai tersebut masih berada di bawah Kriteria Ketuntasan Minimal (KKM) yang telah ditentukan yaitu 70 .

Ketercapaian hasil belajar siswa yang baik harus diimbangi dengan kesadaran pentingnya menerapkan sikap mandiri dalam belajar pada semua mata pelajaran di sekolah dasar. Hal tersebut diperkuat dengan perdapat Bathi, Ali dan Asrori (Tursinawati, Syafrina , \& Suid, 2017: 71) bahwa kemandirian merupakan salah satu faktor yang menentukan keberhasilan siswa, kemandirian ini diperoleh melalui proses realisasi kemandirian dan proses menuju kesempurnaan, sehingga sikap mandiri ini sangat penting dimiliki oleh siapa saja yang ingin sukses dalam hidupnya.

Mulyono (2017: 6910 menyatakan bahwa "Independent of student learning is the extent to which in the learning process students cam come to determine the objectives, materials and learning experience, and evaluation of learning". Dari pendapat Mulyono, dapat diartikan kemandirian siswa adalah kesiapan siswa dalam menentukan tujuan, bahan dan pengalaman belajar, dan evaluasi pembelajaran. Sependapat dengan Mulyono, Ahmadi (Hadijah \& Laksana, 2019) menyatakan bahwa kemandirian belajar adalah belajar mandiri, tidak mengharapkan bantuan dari orang lain. Bagi siswa yang sudah terbiasa mandiri dalam belajar mereka akan cenderung bersikap tenang saat pengerjaan tugas-tugas ketika dihadapkan pada sebuah masalah, dikarenakan mereka mempunyai kepercayaan diri yang tinggi sehingga mereka tidak mudah terpengaruh oleh pendapat orang lain (Handayani \& Hidayat, 2018). Hasan Basri (Aziz, 2017) menyatakan kemandirian belajar siswa dipengaruhi oleh beberapa faktor yaitu faktor endogen atau faktor dari dalam dan faktor eksogen atau faktor dari luar.

Permasalahan kemandirian merupakan faktor yang dapat menghambat siswa dalam kegiatan pembelajaran salah satunya pada mata pelajaran IPS seperti yang didapatkan dari hasil observasi di SDN 6 Panjer dan SDN 1 Adikarso. Jika pembelajaran IPS terhambat, maka hasil belajar siswa pada mata pelajaran IPS tidak optimal. IPS merupakan salah satu mata pelajaran yang berkaitan dengan berbagai aspek dalam kehidupan. Menurut Susanto (2016) Ilmu pengetahuan sosial (IPS) merupakan ilmu pengetahuan yang mengkaji berbagai disiplin ilmu sosial dan 
humaniora serta kegiatan dasar manusia. Miftahudin (2016) menyatakan IPS adalah ilmu sosial yang mengangkat konsep dan teori-teori ilmu sosial secara terintegrasi untuk memahami, mempelajari, memikirkan pemecahan masalah yang dihadapinya, sehingga memberi kepuasan bagi individu, dengan tujuan mendidik anak menjadi warga negara yang baik. Pada penlitian ini, indikator kemandirian menggunakan pendapat dari Covey (Sa'diyah, 2017), Masrun dkk, (Sa'diyah, 2017), dan Hidayati (Aslamiyah, Setyosari, \& Praherdhiono, 2019) dengan kesimpulan yang diperoleh mengenai indikator kemandirian yaitu: (1) tidak bergantung kepada orang lain; (2) progresif ; (3) bertanggung jawab; (4) inisiatif, artinya mampu berpikir dan bertindak secara alami serta kreatif; (5) kemantapan diri ; (6) mampu mengambil keputusan. Berdasarkan uraian di atas, penelitian ini dilakukan dengan tujuan: (1) menganalisis ada tidaknya hubungan antara kemandirian belajar siswa dan hasil belajar IPS siswa kelas V SDN se-Kecamatan Kebumen tahun ajaran 2020/2021, dan (2) menganalisis besarnya sumbangan kemandirian belajar terhadap hasil belajar IPS siswa kelas V SDN se-Kecamatan Kebumen tahun ajaran 2020/2021.

\section{METODE}

Penelitian ini merupakan penelitian kuantitatif dengan metode korelasi. Winarni (Wahyunu, Dalifa \& Muktadir, 2017) menyatakan penelitian korelasional adalah penelitian yang menghubungan antara variabel atau beberapa variabel dengan variabel lain. Pada penelitian ini, peneliti mengaitkan hubungan kemandirian belajar dan hasil belajar IPS siswa kelas V SDN se-Kecamatan Kebumen Tahun Ajaran 2020/2021.

Populasi penelitian ini yaitu siswa kelas V SDN se-Kecamatan Kebumen sejumlah 1.554 siswa, sampel sebanyak 319 siswa, dan sampel yang diperoleh sebanyak 329 siswa di 12 SD Negeri di Kecamatan Kebumen yang dipilih secara acak dengan teknik cluster random sampling dengan bantuan aplikasi Statistical Product and Service Solution (SPSS) versi 21.

Teknik pengumpulan data yang digunakan pada penelitian ini yaitu angket dan tes. Angket digunakan untuk mengumpulkan data pada variabel bebas (kemandirian belajar), sedangkan tes digunakan untuk mengumpulkan data pada variabel terikat (hasil belajar).

Uji prasyarat data penelitian ini menggunakan uji linieritas dan uji normalitas. Setelah memenuhi prasyarat, data dianalisis menggunakan uji korelasi sederhana dan koefisien determinasi.

Tabel 1. Distribusi Data Frekuensi Belajar dan Hasil Belajar Matematika

\begin{tabular}{ccccc}
\hline No. & \multicolumn{2}{c}{ Kemandirian Belajar } & \multicolumn{2}{c}{ Hasil Belajar IPS } \\
\cline { 2 - 5 } & Interval & Frekuensi & Interval & Frekuensi \\
\hline 1. & $62-65$ & 14 & $14-23$ & 2 \\
2. & $66-69$ & 24 & $24-33$ & 14 \\
3. & $70-73$ & 50 & $34-43$ & 36 \\
4. & $74-77$ & 61 & $44-53$ & 41 \\
5. & $78-81$ & 65 & $54-63$ & 85 \\
6. & $82-85$ & 51 & $64-73$ & 51 \\
7. & $86-89$ & 29 & $74-83$ & 53 \\
8. & $90-93$ & 15 & $84-93$ & 27 \\
9. & $94-97$ & 10 & $94-100$ & 10 \\
\hline & Total & 319 & Total & 319 \\
\hline
\end{tabular}


Penelitian dilakukan dengan memberikan angket kemandirian belajar dan soal IPS kepada siswa kelas $\mathrm{V}$ di SD yang menjadi sampel penelitian. Pembuatan instrumen kemandirian belajar dikembangkan atas 6 indikator. Aspek-aspek tersebut meliputi kemantapan diri, bertanggung jawab, progresif, inisiatif, mampu mengambil keputusan dan tidak bergantung pada orang lain. Angket yang akan digunakan dalam penelitian ini yaitu angket dengan jenis skala likert berbentuk checklist dengan kriteria sebagai berikut:

\section{Tabel 2 Kriteria Skala Angket Penilaian}

\begin{tabular}{lccccc}
\hline \multirow{2}{*}{$\begin{array}{l}\text { Item } \\
\text { Pertanyaan }\end{array}$} & $\begin{array}{c}\text { Sangat } \\
\text { Setuju } \\
\text { (SS) }\end{array}$ & $\begin{array}{c}\text { Setuju } \\
\text { (S) }\end{array}$ & $\begin{array}{c}\text { Ragu-ragu } \\
\text { (RG) }\end{array}$ & $\begin{array}{c}\text { Tidak Setuju } \\
\text { (TS) }\end{array}$ & $\begin{array}{c}\text { Sangat Tidak } \\
\text { Setuju (STS) }\end{array}$ \\
\hline Positif & 5 & 4 & 3 & 2 & 1 \\
Negatif & 1 & 2 & 3 & 4 & 5 \\
\hline
\end{tabular}

Uji prasyarat data pada penelitian ini telah terpenuhi yaitu data berdistribusi normal dan data linier.

\section{Tabel 3 Hasil Analisis Uji Normalitas Variabel Hasil Belajar IPS}

\begin{tabular}{lr|l|r|r|r|r}
\hline & \multicolumn{1}{c}{ Tests of Normality } \\
\cline { 2 - 8 } & Solmogorov-Smirnov & \multicolumn{3}{c}{ Shapiro-Wilk } \\
\hline HASIL BELAJAR &, 049 & 319 &, 064 &, 989 & 319 &, 015 \\
\hline
\end{tabular}

\section{a. Lilliefors Significance Correction}

Berdasarkan uji normalitas yang telah dilakukan, didapatkan hasil pada kolom Kolmogorov-Smirnov nilai Sig. yaitu 0,064, sehingga dapat diketahui bahwa signifikansi $>0,05$. Oleh karena itu, dapat disimpulkan bahwa terima Ho atau variabel hasil belajar IPS berasal dari populasi yang berdistribusi normal.

Tabel 4 Hasil Analisis Uji Normalitas Variabel Kemandirian Belajar Tests of Normality

\begin{tabular}{l|r|c|c|r|r|r}
\hline & \multicolumn{3}{c}{ Tests of Normality } \\
\cline { 2 - 7 } & Solmogorov-Smirnov & \multicolumn{3}{c}{ Shapiro-Wilk } \\
\hline $\begin{array}{l}\text { KEMANDIRIAN } \\
\text { BELAJAR }\end{array}$ &, 044 & 319 &, $200^{*}$ &, 992 & 319 &, 093 \\
\hline
\end{tabular}

*. This is a lower bound of the true significance.

a. Lilliefors Significance Correction

Berdasarkan uji normalitas yang telah dilakukan, didapatkan hasil pada kolom Kolmogorov-Smirnov nilai Sig. yaitu 0,200, sehingga dapat diketahui bahwa signifikansi $>0,05$. Oleh karena itu, dapat disimpulkan bahwa terima Ho atau variabel kemandirian belajar berasal dari populasi yang berdistribusi normal.

Tabel 4 Hasil Uji Linieritas Hasil Belajar dan kemandirian Belajar ANOVA Table

\begin{tabular}{llllll}
\hline & $\begin{array}{l}\text { Sum of df } \\
\text { Squares }\end{array}$ & $\begin{array}{l}\text { Mean } \\
\text { Square }\end{array}$ & $F$ & Sig. \\
\hline Hasil Belajar * Between (Combined) & 25830.141 & 34 & 759.710 & 3.076 & .000 \\
\hline
\end{tabular}




\begin{tabular}{|c|c|c|c|c|c|c|c|}
\hline \multirow{4}{*}{$\begin{array}{l}\text { Kemandirian } \\
\text { Belajar }\end{array}$} & \multirow[t]{2}{*}{ Groups } & Linearity & 16326.129 & 1 & 16326.129 & 66.112 & .000 \\
\hline & & $\begin{array}{l}\text { Deviation } \\
\text { from } \\
\text { Linearity }\end{array}$ & 9504.605 & 33 & 288.000 & 1.166 & .251 \\
\hline & \multicolumn{2}{|c|}{ Within Groups } & 70132.605 & 284 & 246.946 & & \\
\hline & \multicolumn{2}{|l|}{ Total } & 46 & 318 & & & \\
\hline
\end{tabular}

Berdasarkan uji linieritas yang telah dilakukan, dapat diketahui bahwa Sig. Deviation from Linearity yaitu $\mathbf{0 , 2 5 1}$, sehingga dapat diketahui bahwa signifikansi 0,251 $>0,05$. Oleh karena itu, dapat disimpulkan bahwa Ho diterima atau terdapat hubungan linier antara hasil belajar IPS siswa kelas $\mathrm{V}$ dan variabel kemandirian belajar.

Tabel 5 Hasil Analisis Korelasi Kemandirian Belajar dengan Hasil Belajar IPS Correlations

\begin{tabular}{llrr}
\hline & & \multicolumn{1}{c}{$\begin{array}{c}\text { Kemandirian } \\
\text { Belajar }\end{array}$} & \multicolumn{1}{c}{$\begin{array}{c}\text { Hasil } \\
\text { Belajar IPS }\end{array}$} \\
\hline $\begin{array}{l}\text { Kemandirian } \\
\text { Belajar }\end{array}$ & $\begin{array}{l}\text { Pearson } \\
\text { Correlation }\end{array}$ & 1 & $.412^{* *}$ \\
\cline { 2 - 4 } & Sig. (1-tailed) & & .000 \\
\cline { 2 - 4 } & $\mathrm{N}$ & 319 & 319 \\
\hline Hasil Belajar IPS & $\begin{array}{l}\text { Pearson } \\
\text { Correlation }\end{array}$ & $.412^{* *}$ & 1 \\
\cline { 2 - 4 } & Sig. (1-tailed) & .000 & \\
\cline { 2 - 4 } & $\mathrm{N}$ & 319 & 319 \\
\hline
\end{tabular}

**. Correlation is significant at the 0.01 level (1-tailed).

Berdasarkan hasil pengujian hipotesis menggunakan SPSS versi 21 menunjukkan bahwa nilai Sig. (1-tailed) yaitu 0,000. Nilai Sig. tersebut $<\alpha(0,05)$, artinya hipotesis penelitian ini dapat diterima atau terdapat korelasi positif antara kemandirian belajar dan hasil belajar IPS siswa kelas V SDN se-Kecamatan Kebumen tahun ajaran 2020/2021. Hasil analisis koefisien korelasi antara variabel kemandirian belajar dan hasil belajar IPS yaitu 0,412. Berdasarkan pedoman interpretasi nilai koefisien korelasi versi De Vaus dapat diketahui bahwa koefisien korelasi pada penelitian ini yaitu 0,412 berada pada tingkat hubungan moderat/sedang.

Sumbangan kemandirian belajar terhadap hasil belajar IPS dianalisis dengan menggunakan rumus koefisien determinan oleh Riduwan dan Sunarto (2014) sebagai berikut :

$$
K P=r^{2} \times 100 \%
$$

Hasil perhitungan koefisien determinan dalam persen variabel kemandirian belajar pada hasil belajar IPS didapatkan hasil sebesar $16.9 \%$ dengan koefisien determinasi sebesar 0,169. Oleh karena itu, dapat disimpulkan bahwa besarnya sumbangan variabel kemandirian belajar pada hasil belajar IPS yaitu sebesar $16.9 \%$ dan sisanya $83.1 \%$ dipengaruhi oleh faktor lain. Relevan dengan penelitian dari Nurelah (2016) yang menunjukan terdapat hubungan dari kemandirian belajar peserta didik dengan hasil belajar IPS peserta didik kelas $V$ di SDN Wilayah Binaan IV 
Pulogadung, Jakarta Timur, sebesar $48,5 \%$ sedangkan sisanya $51,5 \%$ merupakan faktor lain.

Berdasarkan penelitian dan perhitungan yang telah dilakukan, dapat diketahui bahwa kemandirian belajar mempunyai hubungan positif dengan hasil belajar IPS dengan nilai $r$ hitung $(0,412)>r$ tabel $(0,109)$. Relevan dengan penelitian dari Yusuf (2017: 15) yang menunjukkan ada hubungan yang signifikan antara kemandirian belajar siswa dengan hasil belajar siswa pada mata pelajaran IPS. Semakin tinggi kemandirian belajar siswa, maka akan semakin tinggi pula hasil belajar IPS siswa. Begitu pun sebaliknya, semakin rendah kemandirian belajar siswa, maka akan rendah pula hasil belajar IPS siswa. Dari data tersebut menunjukkan bahwa dalam meningkatkan hasil belajar memerlukan adanya peningkakatn kemandirian belajar siswa.

\section{SIMPULAN}

Berdasarkan hasil penelitian dan pembahasan hubungan kemandirian belajar dan hasil belajar IPS siswa kelas V SDN se-Kecamatan Kebumen tahun ajaran 2020/2021 dapat ditarik kesimpulan bahwa: (1) Kemandirian belajar berkorelasi positif dengan hasil belajar IPS siswa kelas V SDN se-Kecamatan Kebumen tahun ajaran $2020 / 2021$ dengan tingkat korelasi sedang yaitu 0,412; (2) Sumbangan variabel kemandirian belajar terhadap hasil belajar IPS sebesar $16.9 \%$ (tidak bergantung kepada orang lain, progresif, bertanggung jawab, inisiatif, kemantapan diri, mampu mengambil keputusan) dan sisanya $83.1 \%$ dipengaruhi oleh faktor lain. Penerapan kemandirian belajar dapat dilakukan dengan berbagai cara seperti menerapkan proses pendidikan yang berdemokrasi dengan memberikan kesempatan kepada siswa untuk berpendapat ataupun bertanya dan memberikan kebebasan kepada siswa untuk mencoba atau mengeksplorasi lingkungan sehingga dapat mendorong rasa ingin tahu siswa, 3) Selain menerapkan pendidikan yang berdemokrasi, penerapan diskusi kelompok dan penugasan dalam pembelajaran juga dapat melatih kemandirian belajar siswa. Melalui diskusi siswa dilatih untuk mengemukakan pendapat, memecahkan masalah, dan bertanggung jawab dengan hasil yang telah dikerjakan, sedangkan melalui penugasan seperti PR, siswa akan terlatih lebih mandiri dalam belajar. Peningkatan kemandirian juga perlu didukung oleh sarana dan prasarana yang memadai.

Berdasarkan simpulan yang telah disebutkan, dapat diberikan beberapa saran yakni : (1) Guru hendaknya memperhatikan kemandirian belajar siswa dengan memancing kemandirian belajar siswa dalam setiap pembelajaran, agar siswa terbiasa untuk menerapkan kemandirian belajar di sekolah maupun di rumah, sehingga dapat meningkatkan hasil belajar. (2) Sebaiknya sekolah menyediakan fasilitas, sarana, dan prasarana seperti pengadaan buku-buku yang berkaitan dengan pembelajaran IPS, pengadaan alat peraga, dan menyiapkan soal-soal latihan serta mendukung guru untuk berinovasi dalam meningkatkan kemandirian belajar. (3) Orang tua/wali siswa hendaknya memperhatikan kemandirian belajar siswa dan membimbing kegiatan belajar siswa dengan mengatur dan mengawasi jadwal belajar siswa. (4) Bagi peneliti selanjutnya yang ingin mengkaji tentang kemandirian belajar dan hasil belajar IPS siswa dapat menjadi acuan dalam penelitian korelasi dan diharapkan mencari sumber refensi lainnya agar nanti penelitiannya jauh lebih baik dengan menggunakan indikator yang berbeda dari penelitian sebelumnya. 


\section{DAFTAR PUSTAKA}

Aslamiyah, T. A., Setyosari, P., \& Praherdhiono, H. (2019) Blended Learning dan Kemandirian Belajar Mahasiswa Teknologi Pendidikan. JKTP Jurnal Kajian Teknologi Pendidikan, Vol 2 No (2) Mei (2019): 109-114.

Aziz, A. (2017). Hubungan antara Kompetensi Guru dan Kepercayaan Diri dengan Kemandirian Siswa SMP N 2 Pangkalan Susu. Jurnal Psychomutiara, Volume 1 No 12017.

Hadijah, H.S \& Laksana, A.P (2019). Kemandirian Belajar sebagai Determinan Hasil Belajar Siswa. Jurnal Pendidikan Manajemen Perkantoran. Vol. 4 No. 1, Januari 2019.

Handayani, N. \& Hidayat, F. (2018). Hubungan Kemandirian terhadap Hasil Belajar Siswa Mata Pelajaran Matematika di Kelas X SMK Kota Cimahi. Journal On Education, Volume 01, No. 02, Februari 2018.

Miftahuddin. (2016). Revitalisasi IPS dalam Perspektif Global. Jurnal Tribakti. Volume 27 Nomor 2, September 2016.

Mulyono, D. (2017). The Influnce Of Learning Model and Learning Independence on Matematics Learning Outcomes by Controlling Student Early Ability. Internasional Electronik Journal of Matematics Educations 12 (13), 689-708.

Nurelah, E. (2016). Kemandirian Belajar Dan Kecerdasan Interpersonal Dengan Hasil Belajar IPS Peserta Didik Kelas V Sdn Di Wilayah Binaan IV Pulogadung Jakarta Timur. Jurnal Pendidikan Dasar, 7(1), 13-26.

Riduwan \& Sunarto. (2014). Pengantar Statistika untuk Penelitian Pendidikan, Sosial, Ekonomi, Komunikasi, dan Bisnis. Bandung: Alfabeta.

Sa'diyah, R. (2017). Pentingnya Melatih Kemandirian Anak. KORDINAT Vol. XVI No. 1, April 2017

Susanto, A. (2016). Teori Belajar dan Pembelajaran di Sekolah Dasar. Jakarta: Prenadamedia.

Tursinawati, Syafrina., \& Suid. (2017). Analisis Kemandirian Siswa dalam Proses Pembelajaran di Kelas III SD Negeri 1 Banda Aceh. Jurnal Pesona Dasar, 1(5), $70-81$.

Yusuf, G. G. (2017) Hubungan Kemandirian Belajar Siswa dengan Hasil Belajar Siswa pada Mata Pelajaran IPS Terpadu Kelas VII di SMP Negeri 2 Kandangan Kabupaten Hulu Sungai Selatan. JPG (Jurnal Pendidikan Geografi).

Wahyunu, Dalifa \& Muktadir. (2017). Hubungan Antara Pendidikan dalam Keluarga dengan Sikap Rasa Hormat Siswa Kelas IV Sd Negeri 03 Kota Pagar Alam. Jurnal PGSD: Jurnal IImiah Pendidikan Guru Sekolah Dasar, 10 (2) 2017. Hal.86-91 PGSD FKIP Universitas Bengkulu. 